\title{
Factors Influencing the Development of CSR Reporting Practices: Experts' versus Preparers' Points of View
}

\author{
Patrycja Habek, Radosław Wolniak
}

\author{
Silesian University of Technology \\ Roosevelta st. 26-28, 41-800 Zabrze, Poland \\ E-mail.patrycja.habek@polsl.pl; radoslaw.wolniak@polsl.pl
}

cross $^{\text {ref }} \underline{\text { http://dx.doi.org/10.5755/j01.ee.26.5.7690 }}$

\begin{abstract}
Reporting of corporate social responsibility (CSR) is nowadays becoming an important and rapidly growing phenomenon in the world. The current increase in the number of companies reporting on CSR data is caused by many different factors, including stakeholder pressures, the economic crisis, growing awareness of sustainability issues as well as the appearance of more and more new reporting requirements initiated by national governments and stock exchanges.

Despite the growing popularity of CSR reporting, it is still only a small percentage of companies that decide to regularly disclose their data on CSR activities. Therefore, the question is raised as to what factors influence the development of CSR reporting practices. The paper presents the results of the research, which aimed to answer the above question, highlighting especially the role of government in the process.

The study was carried out using two web-based surveys. The questionnaires were distributed to respondents from different European Union member states. The first group of respondents consisted of specialists, consultants, researchers and academics specializing in the field of CSR reporting - 'experts' - and the second group consisted of CSR managers, employees involved in developing CSR reports - 'preparers'.

The results suggest that report 'preparers' and external 'experts' have different views on some aspects, e.g., reasons to issue a CSR report. The survey also shows that there is a need for the greater participation of government in the development of sustainability reporting practices.
\end{abstract}

Keywords: Corporate Social Responsibility Reporting, Sustainability Reporting, Determinants, Drivers And Barriers, Public Sector Role.

\section{Introduction}

The increasing expectations of stakeholders regarding the transparency and accountability of companies imply measuring and disclosing the impact of business decisions on society and the environment (Amran et al., 2014). The practice of disclosing corporate social responsibility (CSR) data is becoming more and more popular, especially among large companies (Habek, 2014; GRI, 2012). In recent years, the number of companies publishing sustainability reports has increased significantly (Azzone \& Bertele, 1994). According to statistics, at the global level, this number has increased from almost zero in 1992 to over 66,000 today (data according to corporateregister.com database). Terminology used for these kinds of reporting practices varies in literature and business practice. Research conducted by the KPMG in 2013 (KPMG, 2013) shows that the most commonly used terms by companies globally are 'sustainability' report $(43 \%)$, 'corporate social responsibility', CSR (25\%), and 'corporate responsibility' (14\%) report. In this paper the authors use these terms interchangeably. CSR reporting refers to the provision of useful information for external and internal stakeholders on the economic, environmental and social results achieved by an organization. The disclosed information is usually provided in the form of a CSR report - a document which provides information about the company's planned and ongoing responsible business practices taking into account stakeholder expectations (Borga et al., 2009; Dagiliene et al., 2014). Some companies choose to include the CSR information in their annual reports, while others publish such information in the form of a standalone report or announce it through a sustainability website.

We can risk making the statement that sustainability reporting is becoming a global standard (Ullmann, 1985; Dechant \& Altman, 1994; Cho \& Pucik, 2005; Ciegis \& Grunda, 2006; Laidroo \& Ööbik, 2014; Gao, 2011) but despite the growing popularity it is still only a small percentage of companies which decide to regularly disclose their data on CSR activities. Therefore, a question arises which is simultaneously the research problem of the study: what factors influence the development of CSR reporting practices? The aim of the study, results of which are presented in this paper, was to identify the enablers of and barriers to the development of sustainability reporting, highlighting especially the role of government in the process. The authors specifically sought the perspectives of different stakeholders, i.e., sustainability managers/persons responsible for preparing a sustainability report, specialists connected with CSR concept promotion from different institutions and organizations, including NGOs and academics. The subject of the research was the factors affecting the development of CSR reporting practices in the European Union, emphasizing especially different governmental initiatives in this area. Currently we can observe an upward trend in the activity of governments 
around the world in the implementation of regulations in the area of CSR reporting (KPMG et al., 2010). Additionally, governments encourage and support companies in the disclosure of CSR data using various instruments or their combinations (Habek \& Wolniak, 2013). The research methodology included the theoretical and empirical analysis. The theoretical analysis was based on the literature on CSR reporting, its determinants and the public sector's role in the development of those practices. Empirical analysis was based on results of an Internet survey dedicated to two groups of respondents from different European Union member states.

The paper contributes to the research on CSR reporting practices in the European Union and its determinants with a particular focus on the role of government in the development of those practices. The novelty and distinguishing characteristic of this study is that the factors influencing the development of CSR reporting practices were assessed through the perspectives of different stakeholders and by respondents from different European Union member states. The paper is divided into four sections: the literature review, the "methodology" section, which details the research process and describes the sample, followed by the "results" section which reports the findings. In this chapter the authors firstly discuss the opinion of experts and then they present a comparison of the opinions of two different groups of respondents. The last is the "conclusions" section which considers the findings and indicates the most important directions for developing CSR reporting practices.

\section{Literature Review}

One of the consequences of the current financial crisis is a loss of social confidence (Maruszewska, 2010). Therefore, it is reasonable to consider the topic of reporting on non-financial data. In order to make informed choices and rational investment decisions, consumers and investors increasingly demand that companies report on their CSR activities (Cowen et al., 1987; Berglof \& Pajuste, 2005). We can say that the concept of corporate social responsibility (CSR) is based on companies attaining a balance between the interests of all their stakeholders within their strategic planning and operations (Auperle et al., 1985). We can define CSR as a concept whereby companies decide voluntarily to contribute to a better society and cleaner environment (Belkaoui \& Karpik, 1989; Albareda et al., 2007). Today, CSR is widely seen as a management strategy option (Streimikiene \& PuSinaite, 2009) and this is the case for various widespread CSR reporting practices. Furthermore, corporate social responsibility defines a concern for the organization for society, taking responsibility for the impact of activities on customers, suppliers, employees, shareholders, communities and the environment (Cepinskis \& Sakalauskaite, 2009; Guzavicius \& Bruneckiene, 2010). Therefore, the concept of corporate social responsibility involves the dynamics of relations with the public (Vormedal \& Ruud, 2009; Vveinhardt \& Andriukaitiene, 2014). Corporate social responsibility is at heart a process of managing the costs and benefits of business activities to both international and external shareholders (Fox et al.,
2002). As we can see, the concept of CSR is characterized by a wide range of topics (Berber et al., 2014) and a multiplicity of stakeholders whose expectations the company should take into account. There are many reasons for a company to be socially responsible (Burke \& Logsdon, 1996; Sprinkle \& Maines, 2010). Besides the benefits of improved image, many companies today perceive social responsibility as a way to better manage human resources and their supply chain (Maloni \& Brown, 2006) which in turn has led to an increase in their competitive advantage (Kolk 2003; O'Dwyer et al., 2005; Juscius \& Snieska, 2008; Morhardt 2010; McWilliams \& Siegel, 2011; Qinghua, 2014). The CSR report is one way a company can communicate (Du et al., 2010) with stakeholders or wider society about its social responsibility. On the other hand, this kind of report can act as a managerial tool (Adams \& Frost, 2008) to monitor and improve CSR concept implementation in a company. CSR reporting practices vary widely. Some enterprises publish information on their sustainability performance as part of their annual reports (Dagiliene, 2010), some of them in separate corporate social responsibility (CSR) reports, and sometimes both. Some of the reports are prepared according to international standards and guidance and some are not. The common feature of these practices is the continuous increase in the number of companies that disclose CSR data.

In connection with the growing interest in CSR reporting among enterprises, researchers are trying to understand the factors affecting this process (Dagiliene et al., 2010; Goettsche et al., 2014; Stubbs et al., 2013; Habek \& Wolniak, 2013). Research on the reasons why companies develop or do not develop CSR reports has been carried out by different authors. Many of them have explored the determinants of corporate social responsibility reporting and investigated whether internal factors like size and industry or external factors like stakeholder pressures have an impact on such disclosure (Fifka, 2013). According to Kolk (2004), societal aspects such as credibility and reputation have been found to be more important than internal reasons. Other authors (Fifka 2012; Idowu \& Papasolomou, 2007) have found that companies develop CSR reports because they believe that it is necessary to meet stakeholders' requirements. Solomon and Lewis (2002) have found that there is a difference between the information requirements of 'users' (O'Dwyer et al., 2005) and the willingness of 'preparers' to provide it. It is not uncommon that companies preparing the report do not always take into account the expectations of stakeholders (Perrini \& Tencati, 2006). Therefore, published reports often fail to match the principal purpose of such disclosure, which is to provide useful information to stakeholders.

Studies on CSR reporting practices and factors influencing the process were also carried out over several years by KPMG via the International Survey of Corporate Responsibility Reporting issued in 2002, 2005, 2008 and 2013. KPMG surveyed the 250 largest global corporations (G250) to determine drivers for corporate responsibility reporting. The study conducted by (Hossain et al., 2012) reveals that motivations for corporate social and environmental reporting (CSER) mainly derived from 
management leadership, regulators, external stakeholder pressure, branding corporate image, poverty alleviation motives and social obligation motives. The barriers to CSER are attributable to the lack of a regulatory framework, a tendency for non-compliance to the laws, socioeconomic problems, lack of awareness and education in sustainable development, and lack of initiatives from governments.

The government's role in promoting the concept of CSR is also considered in the literature (Midttun 2005; Daub \& Karlsson, 2006; Albareda et al., 2008; Albareda et al., 2007, Steurer, 2010; Moon, 2004; Aaronson \& Reeves, 2002; Rome, 2005; Fox et al., 2002; Streimikiene \& Pusinaite, 2009; Fifka \& Pobizhan, 2014). The research conducted on governments and CSR suggests the emergence of new roles adopted by governments in CSR issues (Matten \& Moon, 2005; Stiller \& Daub, 2007; Gebauer \& Hoffman, 2009; Albareda et al., 2007). Fox et al. (2002) put forward new public sector roles to be adopted by governments to enable an environment for CSR: mandatory (legislative); facilitating (guidelines on content); partnering (engagement with multi-stakeholder processes); and endorsing tools (publicity). However the literature focusing solely on CSR reporting and the governmental/public sector role in the development of those practices is rather limited.

With regard to methodology and aim, most studies have applied content analysis and examined disclosure patterns and internal determinants of reporting. This can be attributed to the fact that the data on variables like size and industry are easy to obtain as the information is provided by the companies themselves or by the media. Moreover, these types of data can be quantified or classified easily. External determinants, e.g., stakeholder pressure, attitudes and perceptions, are not only harder to quantify, but the respective data are also more difficult to gather and interviews or surveys need to be conducted (Fifka, 2013). This paper aims to at least in part fill that gap and to draw attention to existing differences in the perception of determinants of this type of reporting by various stakeholder groups.

\section{Methodology}

As attitudes and perceptions are being studied, the research was conducted using a survey research method, specifically a type of web-based survey. The questionnaires were placed on a dedicated website. Recruitment of survey respondents was based on sending out e-mails (e-mail) with invitations and hypertext links to a web page on which the questionnaire was published. Respondents were invited to participate in the study by information sent to them via e-mail. The authors consider that using such a method is best to access the relevant respondents and to ensure an adequate response rate. The decision to conduct an online survey resulted from the fact that the authors wanted to reach different groups of respondents (practitioners, persons who prepare CSR reports and experts, researchers, scientists in the field) whose e-mail addresses were publicly available.
To ensure anonymity the survey was administered independently of the researcher. This was assured by issuing invitations using an e-mail account specially created for that purpose and by disabling any features on the web survey system that could allow respondents to be traced if they used the hyperlink provided.

Due to the aim of the study the selection of the sample was deliberate. The invitation was sent to two groups of respondents:

- 'experts'- specialists, consultants, researchers and academics specializing in the field of CSR reporting - questionnaire 1

- 'preparers' - CSR managers, employees who take part in developing sustainability reports questionnaire 2 .

The assumption of the study was that the respondents have to be EU citizens. Selection of respondents from EU countries is due to the fact of their being subject to the same EU directives.

For each of these groups, a different version of the questionnaire (questionnaire 1 and questionnaire 2) was prepared, which as well as a common part contained questions specifically for the respective group of respondents. The first questionnaire focused mainly on exploring the respondents' opinion on the role of government in the promotion and development of sustainability reporting practices, and the nature and types of actions undertaken in this regard. The second questionnaire referred particularly to issues of motivation and barriers encountered by businesses when choosing to report on CSR issues. Both questionnaires contained questions related to the general determinants of the development of such practices. The questions used in the questionnaires were based on a literature review focused on CSR reporting determinants as well as previous authors' studies (authors, 2013; author, 2014). The questionnaire design process is shown in Figure 1. A multi-item scale was used because attitude cannot be adequately captured by a single rating scale. In the study a five-point Likert scale was used where 1 is the lowest and 5 is the highest rating. In the Likert scale, the respondents are provided with a range of responses to enable them to indicate how strongly they agree or disagree. To measure their attitudes, a researcher can assign scores to the different responses (Zikmund, 2003). Before conducting the research the authors conducted pre-testing of the survey questionnaire to make it coherent and easy to understand.

E-mail addresses of the first group of respondents (questionnaire 1) were collected from the websites of consultancies organizations, academics and NGOs specializing in the field of CSR concepts and CSR reporting. The selection of e-mail addresses was carried out by the following methods of data acquisition:

- We used all the e-mail addresses of scientists related to the topic of sustainability reporting on the Google Scholar database (sustainability reporting as a group of scientific interests);

- We obtained e-mail addresses from consulting and advisory companies and NGOs related to CSR and CSR reporting by searching for them through the 
Google search engine. We took into consideration the first 20 pages of Google results by entering the name of countries and the keywords: CSR, corporate social responsibility reporting, sustainability reporting.

Addresses of the second group of respondents (CSR report preparers), to whom questionnaire 2 was dedicated, were obtained from the CSR reports published by companies from European Union member states
(Denmark, France, Poland, Sweden, the United Kingdom and the Netherlands). In the study we collected all available addresses from CSR reports published in 2012 and collected in corporateregister.com database, which is the world's largest online directory of past and present corporate responsibility reports. The collected addresses were e-mail contacts for CSR managers or persons responsible for developing CSR reports in a company.

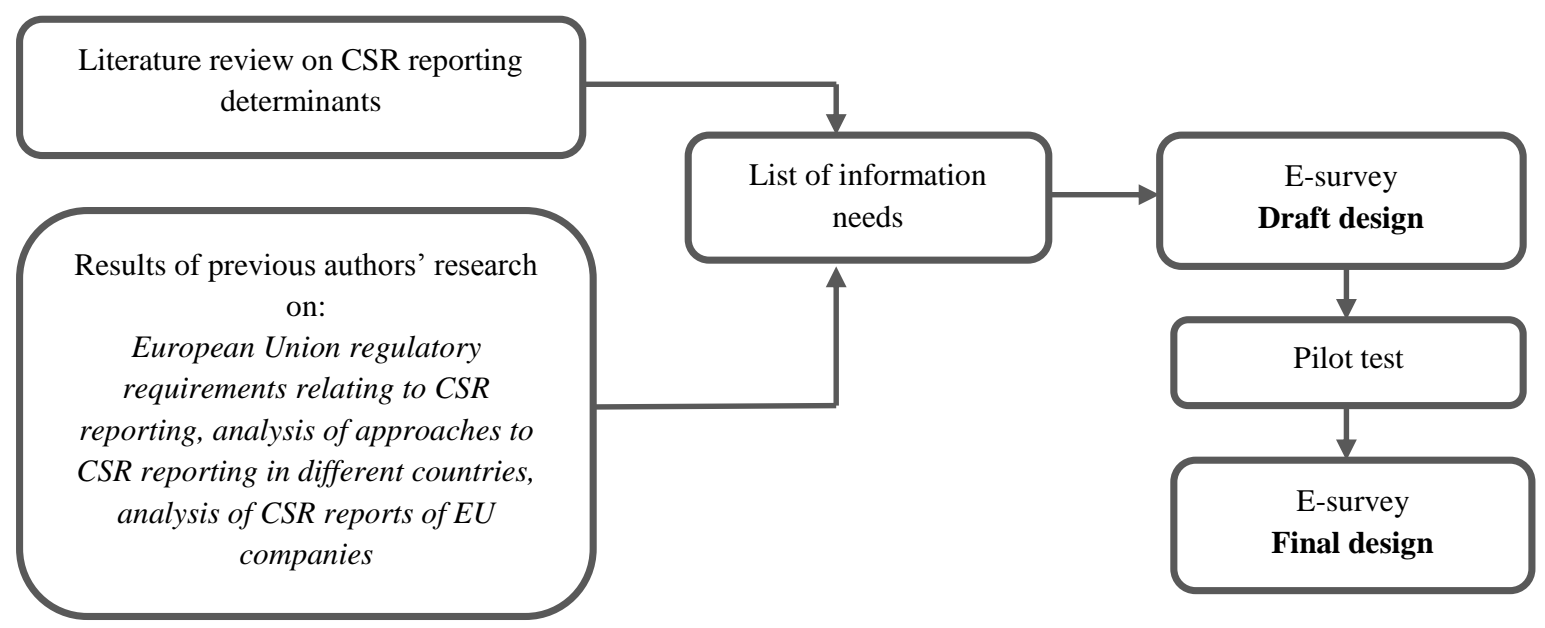

Figure 1. The survey design

The first mailing of the survey was done on 2 April 2014 and 29 surveys were returned. To improve the response rate, two weeks later reminder letters were sent to those respondents that had not answered the first mailing.

A total of 424 invitations to participate in the study were sent via e-mail and 63 web-based surveys were returned; this resulted in a response rate of $15 \%$. Questionnaire 1 gained a greater response rate (19\%) than questionnaire $2(9 \%)$. This means that experts and consultants in the field of CSR were much more willing to respond to the invitation than the CSR managers or employees involved in developing the CSR reports in particular companies.

None of the surveys were eliminated due to incompleteness because it was impossible for the respondent to finish the survey without answering all of the questions.

\section{Sample characteristics}

The results of 63 surveys were analysed. The invitation to participate in the study was accepted the most by Polish respondents $-47 \%$ of the sample - followed by respondents from the United Kingdom (11\%), Italy (5 $\%)$ and Sweden (4\%). Respondents from other countries (Denmark, Austria, Belgium, Croatia, France, Germany, Greece, Ireland, Lithuania, the Netherlands, Portugal, Slovakia, Spain and Switzerland) each represented less than $4 \%$ in the sample. The professional area of respondents in the studied sample is differentiated (see Figure 2). Most respondents in the sample occupy the position of CSR manager (27\%), CSR consultant (24\%) and researcher/academic $(21 \%)$. In the whole sample, 71 $\%$ of respondents have already had a chance to participate in the creation of a CSR report. Respondents to whom questionnaire 2 was dedicated (i.e., CSR managers and employees involved in the creation of CSR reports) in the vast majority (94\%) affirm that the CSR report was prepared in accordance with international guidelines and standards (e.g., GRI, UN Global Compact, AA1000). Furthermore, $75 \%$ of these respondents confirmed that the CSR report was developed with the participation of an external advisory/consulting company.

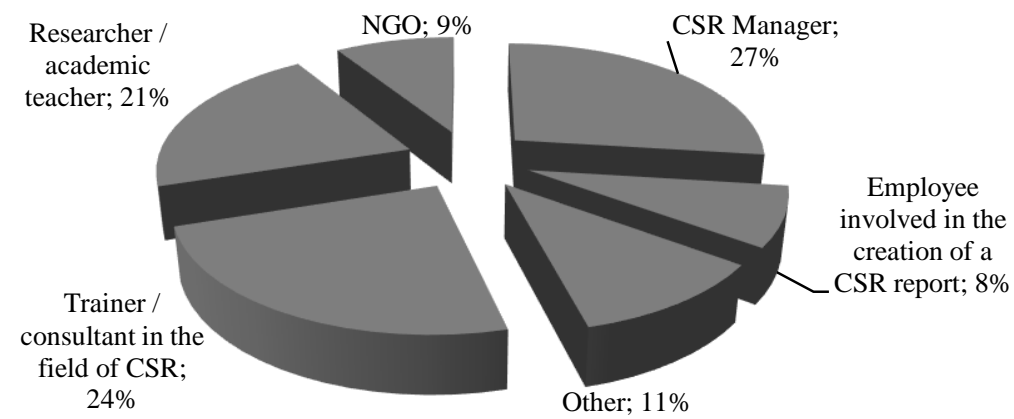

Figure 2. Professional area of respondents in the studied sample 


\section{Results}

In this study two surveys were conducted which examined the attitude of respondents to the issue of sustainability reporting development. Factors influencing the growth of disclosure of such data were examined; in the first stage, government activities, both desired and current, in this area in particular, followed by drivers and barriers for a company to develop a sustainability report.

Taking into account the results of the first survey, addressed to experts/specialists in the field of CSR, the identification of the most important factors influencing the development of sustainability reporting practices has been made in terms of their significance. The results concerning governmental activities in this field (assessment scale from 1 to 5 , where 1 means that the initiative is not important while 5 means that it is very important) are summarized in Table 1. The opinions of the respondents are presented as the answers to the three questions: What should the role of the government be in the development of CSR reporting? What is the current role of the government in the development of CSR reporting? What is the importance of different initiatives undertaken by the government or in cooperation with the government?

The importance of factors influencing the development of CSR reporting in the opinion of CSR experts

\begin{tabular}{|c|c|c|}
\hline Variable & $\begin{array}{l}\text { Average of points } \\
\text { obtained in the } \\
\text { 'expert' assessment }\end{array}$ & Standard deviation \\
\hline \multicolumn{3}{|c|}{ What should the role of the government be in development of CSR reporting? } \\
\hline Legislative regulations & 3,64 & 1,15 \\
\hline Promotional initiatives & 4,17 & 0,84 \\
\hline Educational initiatives & 4,34 & 0,73 \\
\hline Financial support for initiatives & 3,02 & 1,24 \\
\hline Demonstrating a good example & 4,38 & 0,97 \\
\hline \multicolumn{3}{|c|}{ What is the current role of the government in the development of CSR reporting? } \\
\hline Legislative regulations & 1,81 & 0,92 \\
\hline Promotional initiatives & 2,13 & 1,01 \\
\hline Educational initiatives & 2,06 & 1,13 \\
\hline Financial support of initiatives & 1,87 & 0,92 \\
\hline Demonstrating a good example & 1,96 & 1,14 \\
\hline \multicolumn{3}{|l|}{ The importance of government/public sector initiatives } \\
\hline $\begin{array}{l}\text { Creation of tools supporting the development of CSR reports such as manuals, guides and } \\
\text { guidelines containing good examples of CSR reports }\end{array}$ & 3,62 & 1,05 \\
\hline Creating tools and instruments to compare CSR reports & 3,36 & 1,05 \\
\hline Establishing awards and prizes at the national level for the best-prepared CSR report & 3,47 & 1,27 \\
\hline $\begin{array}{l}\text { Encouraging the use of international standards and promoting CSR reporting, e.g., GRI, UN } \\
\text { Global Compact, by reference to these in national policies, sustainable development strategies } \\
\text { and legislation }\end{array}$ & 3,98 & 0,97 \\
\hline Financial support & 3,40 & 1,36 \\
\hline Contribution to the costs of creating CSR report (e.g., independent verification of the report) & 2,62 & 1,34 \\
\hline
\end{tabular}

Answering the question "What should the role of the government be in the development of CSR reporting?" the CSR experts/specialists pointed mainly to issues related to demonstrating a good example - 4,38 (involvement through publication of CSR reports by government administration, companies with state ownership, state-owned companies), and educational $(4,34)$ and promotional $(4,17)$ initiatives. Less important initiatives according to the respondents relate to the legislative process of CSR reporting $(3,64)$ and the financial support for initiatives related to disclosing CSR issues $(3,02)$. On the other hand, according to other studies conducted by the authors of the paper, legal regulations are an important element affecting the quality of CSR reports, and in accordance with the study a correlation exists between the legislation and the quality level of reports developed by organizations.

With regard to the assessment of the current initiatives undertaken by the government, the study shows that this is at a much lower level compared with the respondents' expectations in this area (first question in Table 1). The best rated, promotional initiatives, gained only 2,13 points on a five-point scale, which is relatively low. Very large gaps exist in the area of governments demonstrating a good example, which was rated very low by the respondents $(1,96)$. On the other hand, the analysis of the desired governmental role in the development of CSR reporting practices (first question, Table 1) shows that this type of action is very much expected by those groups of respondents $(4,38)$. In this case, the biggest gap exists between expectations and the actual state of government's role.

Regarding the importance of various types of initiatives desired to be undertaken by the government or in cooperation with the government (question 3 , Table 1), the respondents pointed out firstly the encouragement of the use of international standards (e.g., GRI and UN Global Compact with reference to these in national policies, sustainable development strategies and legislation) with 3,98 , and in the following places indicated the creation of tools supporting the development of the CSR report such as manuals, guides and guidelines containing good examples of CSR reports $(3,62)$, and the encouragement of companies through establishing award programmes for such reports $(3,47)$. The lower scores were obtained by issues related to the participation of the state in the costs of report 
development $(2,62)$. The majority of respondents have the opinion that companies should bear the costs of report preparation themselves. Creating tools and instruments to compare CSR reports (which gives the possibility for improvement) was rated low too, which can be explained by the fact that at the current stage of CSR reporting practices, tools supporting CSR report development are more important than tools for their comparison.

The assessment of initiatives currently undertaken by government or with the participation of government revealed that most initiatives undertaken, in the opinion of the respondents, involve the creation of tools supporting the development of CSR reports, such as manuals, guides and guidelines $(62 \%)$, and the promotion of best practices and good examples of CSR reporting (26\%). The results of actions currently undertaken by the government are reflected in respondents' expectations relating to different types of government initiatives. However a huge gap exists between respondents' expectations and the current state of affairs in the area of government encouragement in the use of international standards, e.g., GRI and UN Global Compact, by reference to these in national policies, sustainable development strategies and legislation. The respondents identified these activities as the most desired type of governmental initiatives in the CSR reporting development process, and only $2 \%$ of respondents claim that such activities are currently undertaken by the government.

Respondents had the opportunity to freely express their views on the subject, and their opinions were as follows: other government activities should include "responsible public procurement policy", "appreciation for companies issuing CSR report", "recommendation for the financial market", and, "The government should promote the CSR concept more instead of reporting, but the government does nothing".

Later the authors decided to compare the ratings of the first and second group of respondents. We wanted to find out what the opinions of the different groups of respondents were concerning the development of CSR reporting from perspectives both outside and inside the company (the opinion of CSR experts/specialists from consulting firms, consultancies and NGOs as well as the opinion of employees of companies which prepare CSR reports). The authors analysed the results obtained in four areas: the role of government, CSR reporting determinants, and drivers and barriers in the creation of a CSR report. The results are summarized in Table 2.

The importance of factors influencing the development of CSR reporting: Comparison of opinions of 'experts' versus 'preparers'

\begin{tabular}{|c|c|c|}
\hline \multirow[b]{2}{*}{ Variables } & \multicolumn{2}{|c|}{ An average of points obtained in the assessmen } \\
\hline & $\begin{array}{c}\text { 'preparers' } \\
\mathbf{N}=16\end{array}$ & $\begin{array}{c}\text { 'experts' } \\
\mathbf{N}=47\end{array}$ \\
\hline \multicolumn{3}{|c|}{ The role of government: } \\
\hline Legislative regulations & 3,64 & 4,42 \\
\hline Promotional initiatives & 4,17 & 3,67 \\
\hline Educational initiatives & 4,34 & 3,92 \\
\hline Financial support for initiatives & 3,02 & 2,92 \\
\hline $\begin{array}{l}\text { Demonstrating a good example (involvement through publishing their own CSR } \\
\text { reports; government administration, companies with state ownership, state-owned } \\
\text { companies) }\end{array}$ & 4,38 & 4,25 \\
\hline \multicolumn{3}{|c|}{ General determinants of CSR reporting development: } \\
\hline Level of social awareness & 3,94 & 4,38 \\
\hline Level of knowledge of entrepreneurs & 4,38 & 3,63 \\
\hline Level of knowledge of public administration & 3,72 & 3,50 \\
\hline Economic situation of a country & 3,02 & 3,19 \\
\hline CSR concept maturity & 3,87 & 3,81 \\
\hline Specific legal regulations regarding CSR reporting & 4,02 & 4,25 \\
\hline Presence of national standards and guidelines for CSR reporting & 3,19 & 3,56 \\
\hline Governmental financial support & 3,04 & 2,75 \\
\hline \multicolumn{3}{|c|}{ Reasons for issuing CSR report: } \\
\hline Willingness to distinguish themselves & 3,87 & 3,88 \\
\hline Meeting the needs of customers & 3,38 & 3,81 \\
\hline Meeting the needs of employees & 2,87 & 3,56 \\
\hline Meeting the needs of society & 3,00 & 4,19 \\
\hline Meeting the needs of investors & 3,64 & 4,00 \\
\hline Meeting the needs of shareholders & 3,36 & 3,94 \\
\hline Fulfilment of legal obligations & 3,00 & 3,69 \\
\hline Improving company’s image & 4,13 & 3,94 \\
\hline Willingness to disclose true and fair organizational view & 2,87 & 4,44 \\
\hline Stakeholder pressure & 3,34 & 3,06 \\
\hline Building trust among key stakeholders & 3,94 & 4,31 \\
\hline Improving processes in organization & 3,13 & 3,88 \\
\hline Better focus on long-term goals & 3,02 & 3,94 \\
\hline Improving risk management & 3,26 & 3,69 \\
\hline \multicolumn{3}{|c|}{ Barriers to developing CSR report: } \\
\hline
\end{tabular}




\begin{tabular}{|c|c|c|}
\hline \multirow[b]{2}{*}{ Variables } & \multicolumn{2}{|c|}{ An average of points obtained in the assessment } \\
\hline & $\begin{array}{c}\text { 'preparers' } \\
\mathrm{N}=16\end{array}$ & $\begin{array}{c}\text { 'experts' } \\
\mathrm{N}=47\end{array}$ \\
\hline The costs of developing CSR report & 3,4 & 3,00 \\
\hline The costs of publishing CSR report & 2,83 & 2,44 \\
\hline Lack of knowledge & 4.19 & 3,25 \\
\hline Lack of interest from stakeholders & 3,74 & 2,88 \\
\hline Voluntary nature of CSR reporting & 3,06 & 3,31 \\
\hline Lack of information & 3,23 & 2,88 \\
\hline Too many guidelines and standards for preparation of such reports & 2,70 & 2,75 \\
\hline Existing guidelines are too general & 2,60 & 2,69 \\
\hline Lack of standardization at the European level & 2,49 & 2,50 \\
\hline Repeating part of the information in other reports produced by the organization & 2,74 & 2,56 \\
\hline
\end{tabular}

Comparing the answers of these two groups of respondents, we can state that the employees/managers from companies that develop CSR reports generally evaluate the role of government as more important in the development of CSR reporting practices than respondents from the external group of CSR experts/specialists. The only element which obtained the opposite result was legislative regulations. External specialists/experts rated this issue as more important $(4,42)$ than managers of firms $(3,64)$. People with practical experience in the field of CSR reporting ("preparers') pay more attention to the "soft" issues and various government initiatives encouraging organizations to create such reports than the legislative initiatives seen as a duty from their point of view. They expect from the government an exemplary attitude in this regard, which seems to confirm the result obtained for the respondents' answer about demonstrating a good example - the type of government role which was rated highest of all selected initiatives $(4,38)$. They expected from the government involvement in the development of CSR reporting practices through publishing their own CSR reports. However the group of external specialists/experts rated the legal regulations as the most important role of government in the development of CSR reporting. They perhaps have a broader view on that issue and do not assess the problem from the perspective of a single company.

Comparing the answers relating to the general determinants of the development of CSR reporting practices, it can be noted that both groups of respondents rated the same determinants highest (level of knowledge of entrepreneurs, level of social awareness, specific legal regulations regarding CSR reporting, and CSR concept maturity) but in a different order. The group of CSR managers rated the level of knowledge of entrepreneurs (4.38) as the most important determinant of development of CSR reporting practices, whereas the external group of CSR experts/specialist rated the level of social awareness highest (4.38). The second-highest rated determinant was the same in both of the surveyed groups: specific regulations regarding CSR reporting. Although the legislative role of government among other initiatives was not highly rated by the group of CSR managers, they consider that legal regulations are an important determinant in the development of CSR reporting. Both groups of respondents also agree that CSR concept maturity in the individual country is an important determinant of the development of CSR reporting practices there. We can suppose that respondents in the sample are aware that without knowledge relating to the CSR concept and its effective implementation, we cannot speak about the development of CSR reporting.

The two surveyed groups of respondents perceive the motives for developing a CSR report differently. The highest rated motives indicated by the group of CSR managers can be classified as image motives: improving the company's image $(4,13)$, building trust among key stakeholders $(3,94)$ and willingness to distinguish themselves $(3,87)$. By contrast, respondents from the second group rated the following motives most highly: willingness to disclose true and fair organizational views $(4,44)$, building trust among key stakeholders $(4,31)$, meeting the needs of society $(4,19)$, and a better focus on long-term goals $(3,94)$. It can be noted that a dissonance occurred between the opinions of these two groups of respondents concerning the reasons for issuing a CSR report. Responses from people associated with the organization that develops the CSR report may suggest that in these enterprises CSR reporting is seen/treated as an element of public relations, improving only the image of the organization, rather than as a real and reliable form of reporting actually undertaken CSR activities. The second group - experts, specialists and scientists - perceive the motives from the perspective of an external observer, more in terms of the theoretical point of view, and indicated as most important those motives that arise from CSR concept awareness and knowledge.

Respondents were also asked to assess external factors/motives that affect the development of CSR reports, i.e., the creation of the kind of reports implied by the desire to meet the needs of different groups of stakeholders. Managers generally rated these kind of motives lower than the group of external experts. Listed in the questionnaire, stakeholders were identified in a different order. Managers rated meeting the needs of investors as the most important reason to issue a CSR report, while external experts indicated meeting the needs of society. These results confirm the previously suggested differences in the perception of the subject of CSR reporting between these two groups of respondents.

An analysis of the barriers to developing a CSR report revealed the differences in respondents' opinions. As the most important barriers, managers indicated: lack of knowledge $(4,19)$, lack of interest from stakeholders $(3,74)$ and costs of developing a CSR report $(3,64)$. The group of external experts consider the biggest barriers to be the 
voluntary nature of CSR reporting $(3,31)$, lack of knowledge $(3,25)$ and costs of developing a CSR report $(3,00)$. The respondents agreed that the cost of preparing a CSR report is an inhibitor of the reporting process. They placed different barriers in first position. The managers rated the lack of knowledge in the field of CSR reporting highest, while external experts looking at the phenomenon globally argued that the most important barrier is the voluntary nature of such practices, an issue that managers rate in only fifth place.

\section{Conclusions}

This paper describes the analysis of factors influencing the development of sustainability reporting practices in the European Union. The objectives of the study were to understand how sustainability reporting can become widespread, including the role of government in this process, as well as to explore the drivers and barriers for companies to develop sustainability reports. The study assesses the influencing factors through different stakeholders' perspectives. These are the major findings:

- Initiatives currently undertaken by the government were rated lower compared with respondents' expectations in this field. This could mean that respondents expect greater participation of government in the development of sustainability reporting practices.

- The role of the government in disseminating CSR reporting practices should, firstly, rely on demonstrating a good example, e.g., publishing CSR reports by government administration, companies with state ownership, state-owned companies, etc., as well as educational and promotional initiatives.

- The majority of respondents have the opinion that financial support from government in the development of CSR reporting practices is less important than other specified initiatives.

- The most important types of governmental initiatives desired by the respondents are: encouraging the use of international standards, e.g., GRI and UN Global Compact $(3,98)$, creating tools such as manuals, guides and guidelines containing good examples $(3,62)$, and encouraging companies through establishing awards programmes for such reports $(3,47)$.

- Managers involved in developing CSR reports generally evaluate the role of government as more important in the development of CSR reporting practices than respondents from the external group of CSR experts/specialists. The only exception is legislative regulations. External specialists/experts rated this issue as more important $(4,42)$ than the managers of firms $(3,64)$, who see the governments' role more in demonstrating a good example.

- Surveyed respondents agree on the most important determinants of the development of CSR reporting practices. The highest rated determinants are: level of knowledge of entrepreneurs, level of social awareness, specific CSR reporting legal regulations, and CSR concept maturity in the individual country. These factors, in the opinion of the surveyed respondents, have the greatest impact on the development of those practices.

- Dissonance occurred between the opinions of the two surveyed groups of respondents in relation to the reasons for issuing a CSR report. The group of managers rated highest the image-related motives, e.g., improving the company's image, whereas the group of external experts indicated an ethical motive, e.g., the willingness to disclose a true and fair view of an organization.

- Managers generally rated those motives arising from the desire to meet the expectations of stakeholders lower than the group of external experts. This could mean that in practice the stakeholders either rarely require the disclosure of such data by companies, or businesses just neglect this kind of incoming message.

- The respondents agree that the cost of preparing a CSR report is an inhibitor of the reporting process, but in the other hand they do not expect financial support from the government.

- As the most important barrier, managers identified lack of knowledge. This situation is confirmed by the fact that $75 \%$ of the surveyed managers use the help of external consulting firms to develop such reports. For the group of external experts, meanwhile, the biggest barrier is the voluntary nature of CSR reporting.

Summing up, the surveyed respondents expect greater participation of government in the development of sustainability reporting practices. Generally they seek government intervention in the form of promotional and educational initiatives which should indicate specific solutions, standards and good examples. On the other hand, they expect specific regulations standardizing the practice of CSR disclosure. The general determinants affecting the development of CSR reporting practices are: level of knowledge of entrepreneurs, level of social awareness, specific legal regulations regarding CSR reporting, and CSR concept maturity. Despite the increasing popularity of these practices among companies, the greatest obstacle still seems to be the lack of knowledge in this field.

\section{Acknowledgements}

This paper has been prepared under the project funded by the National Science Centre Poland awarded on the basis of a decision number DEC-2011/03/B/HS4/01790 


\section{References}

Aaronson, S., \& Reeves, J. (2002). Corporate Social Responsibility in the Global Village: The Role of Public Policy. Washington, DC: National Policy Association.

Adams, C. A., \& Frost, G. R. (2008). Integrating sustainability reporting into management practices. Accounting Forum, 32(4), 288-302.

Albareda, L., Lozano, J. M., \& Ysa, T. (2007). Public policies on corporate social responsibility. The role of government in Europe. Journal of Business Ethics, 74 (4), 391-407.

Albareda, L., Lozano, J. M., Tencati, A., Midttun, A., \& Perrini, F. (2008). The changing role of governments in corporate social responsibility: Drivers and responses. Business Ethics: A European Review, 17(4), 347-363.

Amran, A., Lee, S. P., \& Devi, S. S. (2014). The influence of governance structure and strategic corporate social responsibility toward sustainability reporting quality. Business Strategy and the Environment, 23(4), 217-235. doi: 10.1002/bse. 1767

Azzone, G., \& Bertele, U. (1994). Exploiting green strategies for competitive advantage. Long Range Planning, 27(6), 6981.

Belkaoui, A., \& Karpik, P. G. (1989). Determinants of the corporate decision to disclose social information. Accounting, Auditing and Accountability Journal, 2(1), 36-51.

Berber, N., Susnjar, G. S., Slavic, A., \& Baosic, M. (2014). Relationship between corporate social responsibility and human resource management - as new management concepts - in Central and Eastern Europe. Inzinerine EkonomikaEngineering Economics, 25(3), 360-369. http://dx.doi.org/10.5755/j01.ee.25.3.422

Berglof, E., \& Pajuste, A. (2005). What do firms discloseand why? Enforcing corporate governance and transparency in Central and Eastern Europe. Oxford Review of Economic Policy, 21(2), 178-197.

Borga F.A., Citterio A., Noci G., \& Pizzurno E. (2009). Sustainability report in small enterprises: Case studies in Italian furniture companies. Business Strategy and the Environment, 18(3), 162-176.

Burke, L., \& Logsdon, J. M. (1996). How corporate social responsibility pays off. Long Range Planning, 29(4), $495-502$. DOI: 10.1016/0024-6301(96)00041-6

Cepinskis, J., \& Sakalauskaite, E. (2009). Imoniu socialine atsakomybe ekonomines krizes salygomis Lietuvoje. Taikomoji Ekonomika: Sisteminiai Tyrimai - Applied Economics: Systematic Research, 3(1), 143-162.

Cho, H., \& Pucik, V. (2005). Relationship between innovativeness, quality, growth, profitability, and market value. Strategic Management Journal, 26(6), 555-575.

Ciegis, R., \& Grunda, R. (2006). Sustainable business: The natural step (TNS) framework. Aplinkos tyrimai, inžinerija ir vadyba, 2(36).

Cowen S. S., Ferreri, L. B., \& Parker, L.,D. (1987). The impact of corporate characteristics on social responsibility disclosure: A typology and frequency-based analysis. Accounting, Organizations \& Society 12(2), 111-122.

Dagiliene, L. (2010). The research of corporate social responsibility disclosures in annual reports. Inzinerine EkonomikaEngineering Economics, 21(2), 197-204, available from: http://www.ktu.edu/lt/mokslas/zurnalai/inzeko/67/13922758-2010-22-2-197.pdf

Dagiliene, L., \& Bruneckiene, J. (2010). Savanoriskai atskleidziamos informacijos vaidmuo imoniu socialines atsakomybes aspektu. Ekonomika ir Vadyba-Economics \& Management, 15, 451-456.

Dagiliene, L., Leitoniene, S., \& Grencikova, A. (2014). Increasing business transparency by corporate social reporting: Development and problems in Lithuania. Inzinerine Ekonomika-Engineering Economics, 25(1), 54-61. http://dx.doi.org/10.5755/j01.ee.25.1.2356

Daub, CH., \& Karlsson, Y. (2006). Corporate sustainability reporting: Evidence from the first Swiss benchmark survey. In Schaltegger, S., Bennett, M., \& Burritt, R., (Ed.), Sustainability Accounting and Reporting, (pp. 557-579). Dordrecht: Springer.

Dechant, K., \& Altman, B. (1994). Environmental leadership: From compliance to competitive advantage. Academy of Management Executive, 8(3), 7-28.

Du, S., Bhattacharya, C. B., \& Sen, S. (2010). Maximizing business returns to corporate social responsibility (CSR): The role of CSR communication. International Journal of Management Reviews, 12, 8-19. DOI: 10.1111/j.14682370.2009.00276.x

Fifka, M. S. (2012). The development and state of research on social and environmental reporting in global comparison. Management Review Quarterly, 62(1), 45-84.

Fifka, M. S. (2013). Corporate responsibility reporting and its determinants in comparative perspective - a review of the empirical literature and a meta-analysis. Business Strategy and the Environment, 22(1), 1-35. doi: 10.1002/bse.729

Fifka, M. S., \& Pobizhan, M. (2014). An institutional approach to corporate social responsibility in Russia. Journal of Cleaner Production, 82, 192-201. 
Patrycja Habek, Radosław Wolniak. Factors Influencing the Development of CSR Reporting Practices: Experts'versus ...

Fox, T., Ward, H., \& Howard, B. (2002). Public sector roles in strengthening corporate social responsibility. A baseline study. Washington, DC: World Bank.

Gao, Y. (2011). CSR in an emerging country: A content analysis of CSR reports of listed companies. Baltic Journal of Management, 6(2), 263-291.

Gebauer, J., \& Hoffmann E. (2009). Evaluating extra-financial reporting: The case of the German ranking of sustainability reports. Journal of Applied Accounting Research, 10(3), 224-234.

Goettsche, M., Steindl, T., \& Gietl, S. (2014). Do customers affect the value relevance of sustainability reporting? Empirical evidence on stakeholder interdependence. Business Strategy and the Environment. doi: 10.1002/bse.1856

GRI (2012). The statistics come from the GRI Sustainability Disclosure Database and include information as of 19 April 2012, available from: https://www.globalreporting.org/resourcelibrary/GRI-Reporting-Trends-2011.pdf.

Guzavicius, A., \& Bruneckiene, J. (2010). Ekonominiu interesu grupiu socialine atsakomybe teikiant asimetrine informacija. Ekonomika ir Vadyba - Economics \& Management, 15, 520-524.

Habek, P. (2014). Evaluation of sustainability reporting practices in Poland. Quality \& Quantity, 48(3), 1739-1752. doi $10.1007 / \mathrm{s} 11135-013-9871-\mathrm{z}$

Habek, P., \& Wolniak, R. (2013). Analysis of approaches to CSR reporting in selected European Union countries. International Journal of Economics and Research, 4(6), 79-95.

Hossain, M., Rowe, A. L., \& Quaddus, M. (2012). Drivers and barriers of corporate social and environmental reporting (CSER) practices in a developing country: Evidence from Bangladesh. Interdisciplinary Perspectives on Accounting Conference Proceedings, available from: http://business.cardiff.ac.uk/sites/default/files/ipa2012/Final_Version_IPA_ Paper_Reference_142.pdf.

Idowu, S. O., \& Papasolomou, I. (2007). Are the corporate social responsibility matters based on good intentions or false pretences? An empirical study of the motivations behind the issuing of CSR reports by UK companies. Corporate Governance, 7(2), 136-147.

Juscius, V., \& Snieska, V. (2008). Influence of corporate social responsibility on competitive abilities of corporations. Inzinerine Ekonomika-Engineering Economics, 3(58), 34-44. http://dx.doi.org/10.5755/j01.em.18.1.4005

Kolk, A. (2003). Trends in sustainability reporting by the Fortune Global 250. Business Strategy and the Environment, 12(5), 279-291.

Kolk, A. (2004). A decade of sustainability reporting: Developments and significance. Int. J. Environment and Sustainable Development, 3(1), 51-64. doi: 10.1504/IJESD.2004.004688

KPMG (2013). The KPMG Survey of Corporate Responsibility Reporting 2013. KPMG International, available from: https://www.kpmg.com/Global/en/IssuesAndInsights/ArticlesPublications/corporateresponsibility/Documents/corporate-responsibility-reporting-survey-2013-exec-summary.pdf.

KPMG, United Nations Environment Programme, Global Reporting Initiative, University of Stellenbosch (2010). Carrots and Sticks - Promoting Transparency and Sustainability. An Update on Trends in Voluntary and Mandatory Approaches to Sustainability Reporting. https://www.globalreporting.org/resourcelibrary/Carrots-And-SticksPromoting-Transparency-And-Sustainbability.pdf (accessed 4 June 2014).

Laidroo, L., \& Oobik, U. (2014). Banks' CSR disclosures - headquarters versus subsidiaries. Baltic Journal of Management, 9(1), 47-70.

Maloni, M. J., \& Brown, M. E. (2006). Corporate social responsibility in the supply chain: An application in the food industry. Journal of Business Ethics, 68(1), 35-52.

Maruszewska, E. W. (2010). Etyka i spoleczna odpowiedzialnosc we wspolczesnej rachunkowosci. In J. Zabinska (Ed.), Zeszyty Naukowe Wydziału Zamiejscowego w Chorzowie Wyzszej Szkoty Bankowej w Poznaniu, Wydawnictwo WSB w Poznaniu, 12, 187-196.

Matten, C., \& Moon, J., (2005). A conceptual framework for understanding CSR. In A. Habisch, J. Jonker, M. Wegner \& R. Schmidpeter (Ed.), Corporate Social Responsibility across Europe (pp. 335-356). Berlin: Springer.

McWilliams, A., \& Siegel, D. S. (2011). Creating and capturing value: Strategic corporate social responsibility, resourcebased theory, and sustainable competitive advantage. Journal of Management, 37(5), 1480-1495. doi: $10.1177 / 0149206310385696$

Midttun, A. (2005). Policy making and the role of government realigning business, government and civil society. Emerging embedded relational governance beyond the (neo) liberal and welfare state models. Corporate Governance. The International Journal of Business in Society, 5(3), 159-174.

Moon, J. (2004). Government as a driver of corporate social responsibility: The UK in comparative perspective. ICCSR Research Paper Series, 20, 1-27. The University of Nottingham.

Morhardt, J. E. (2010). Corporate social responsibility and sustainability reporting on the Internet. Business Strategy and the Environment, 19, 436-452. 
O’Dwyer, B., Unerman J., \& Hession E. (2005). User needs in sustainability reporting: Perspectives of stakeholders in Ireland. European Accounting Review, 14(4), 759-787.

Perrini, F., \& Tencati, A. (2006). Sustainability and stakeholder management: The need for new corporate performance evaluation and reporting systems. Business Strategy and the Environment, 15(5), 296-308. doi: 10.1002/bse.538

Qinghua, Z., Hang, Y., Junjun, L., \& Kee-hung L. (2014). How is employee perception of organizational efforts in corporate social responsibility related to their satisfaction and loyalty towards developing harmonious society in Chinese enterprises? Corporate Social Responsibility and Environmental Management, 21(3), 28-40. doi: 10.1002/csr.1302.

Rome, N. (2005). The implications of national agendas for CSR. In A. Habisch, J. Jonker, M. Wegner \& R. Schmidpeter (Ed.), Corporate Social Responsibility across Europe. Berlin: Springer.

Solomon, A., \& Lewis, L. (2002). Incentives and disincentives for corporate environmental disclosure. Business Strategy and the Environment, 11(3), 154-169. doi: 10.1002/bse.328

Sprinkle, G. B., \& Maines, L. A. (2010). The benefits and costs of corporate social responsibility. Business Horizons, $53(5), 445-453$.

Steurer, R. (2010). Corporate social responsibility and the role of governments: Characterising public policies on CSR in Europe. Policy Sciences, 43(1), 49-72.

Stiller, Y., \& Daub, C. H. (2007). Paving the way for sustainability communication: Evidence from a Swiss study. Business Strategy and the Environment, 16(7), 474-486.

Streimikiene, D., \& Pusinaite, R. (2009). The role of public sector in corporate social responsibility development in Lithuania. Ekonomika, 86, 55-67.

Stubbs, W., Higgins, C., \& Milne, M. (2013). Why do companies not produce sustainability reports? Business Strategy and the Environment, 22(7), 456-470. doi: 10.1002/bse.1756

Ullmann, A. A. (1985). Data in search of a theory: A critical examination of the relationships among social performance, social disclosure, and economic performance of U. S. firms. Academy of Management Review, 10(3), 540-557.

Vormedal, I., \& Ruud, A. (2009). Sustainability reporting in Norway - an assessment of performance in the context of legal demands and socio-political drivers. Business Strategy and the Environment 18(4), 207-222.

Vveinhardt, J., \& Andriukaitiene, R. (2014). Social responsibility discourse in empirical and theoretical Lithuanian scientific studies. Inzinerine Ekonomika-Engineering Economics, 25(5), 578-588.

Zikmund, W. G. (2003). Business Research Methods. Chicago: Dryden Press.

The article has been reviewed.

Received in July, 2014; accepted in October, 2015. 